\title{
Recent advances in covalent, site-specific protein
}

\section{immobilization [version 1; peer review: 3 approved]}

\author{
Morten Meldal, Sanne Schoffelen
}

Center for Evolutionary Chemical Biology, Department of Chemistry \& Nano-Science Center, University of Copenhagen, Copenhagen, Denmark

V1 First published: 12 Sep 2016, 5(F1000 Faculty Rev):2303

https://doi.org/10.12688/f1000research.9002.1

Latest published: 12 Sep 2016, 5(F1000 Faculty Rev):2303

https://doi.org/10.12688/f1000research.9002.1

\section{Abstract}

The properties of biosensors, biomedical implants, and other materials based on immobilized proteins greatly depend on the method employed to couple the protein molecules to their solid support. Covalent, site-specific immobilization strategies are robust and can provide the level of control that is desired in this kind of application. Recent advances include the use of enzymes, such as sortase A, to couple proteins in a site-specific manner to materials such as microbeads, glass, and hydrogels. Also, self-labeling tags such as the SNAP-tag can be employed. Last but not least, chemical approaches based on bioorthogonal reactions, like the azide-alkyne cycloaddition, have proven to be powerful tools. The lack of comparative studies and quantitative analysis of these immobilization methods hampers the selection process of the optimal strategy for a given application. However, besides immobilization efficiency, the freedom in selecting the site of conjugation and the size of the conjugation tag and the researcher's expertise regarding molecular biology and/or chemical techniques will be determining factors in this regard.

\section{Keywords}

enzyme-mediated immobilization, self-labeling protein tag, bioorthagonal reactions, oxime ligation, azide-alkyne cycloaddition

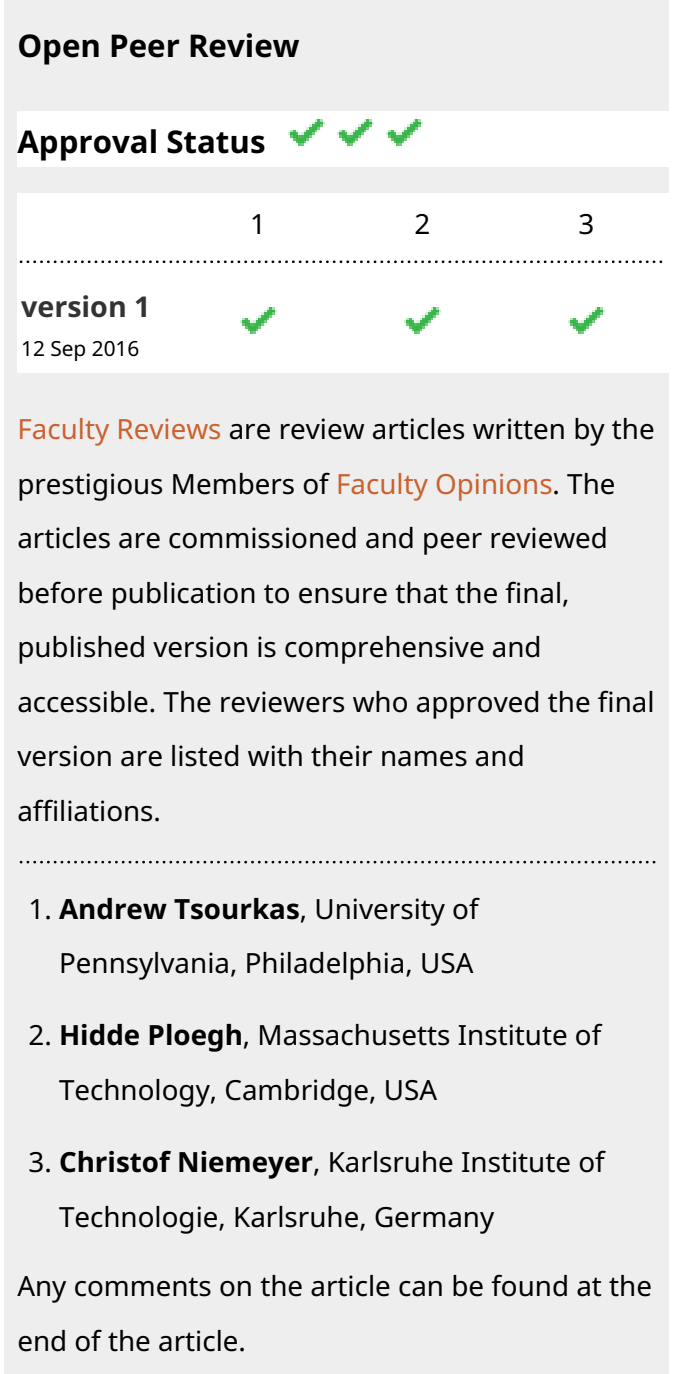


Corresponding author: Sanne Schoffelen (sanne@chem.ku.dk)

Competing interests: The authors declare that they have no competing interests.

Grant information: The authors acknowledge the Danish Council for Independent Research and the European Commission (DFF Mobilex grant 4093-00083) for financial support.

Copyright: ( 2016 Meldal M and Schoffelen S. This is an open access article distributed under the terms of the Creative Commons Attribution License, which permits unrestricted use, distribution, and reproduction in any medium, provided the original work is properly cited.

How to cite this article: Meldal $\mathrm{M}$ and Schoffelen S. Recent advances in covalent, site-specific protein immobilization [version 1; peer review: 3 approved] F1000Research 2016, 5(F1000 Faculty Rev):2303 https://doi.org/10.12688/f1000research.9002.1

First published: 12 Sep 2016, 5(F1000 Faculty Rev):2303 https://doi.org/10.12688/f1000research.9002.1 


\section{Introduction}

Protein immobilization plays an important role in the fields of life science and medicine. It forms the basis for many bio-based applications involving protein-protein or protein-ligand interactions, such as biosensors, biomedical implants, recyclable biocatalysts, and protein arrays for drug screening. For these devices to perform in an optimal manner, a high level of control over the immobilization process is crucial (see Figure 1). In the case of biosensors, such control will ensure that the analyte binding site of a receptor molecule is optimally accessible and a device with maximum sensitivity is generated. Similarly, biocatalysts are preferably immobilized in a directed fashion such that their active site can easily be reached by substrate molecules and, hence, maximum activity is obtained. Control over the immobilization process also contributes to the homogeneity of the surface coverage, such that devices are generated with uniform and welldefined characteristics, providing reproducible and accurate output ${ }^{2}$.

In the past few decades, researchers have devoted substantial effort to developing new strategies for site-specific protein immobilization. Non-covalent approaches, also referred to as affinity-mediated immobilization, include the use of protein $\mathrm{A}$ or $\mathrm{G}$ for binding of antibodies, peptide tags such as polyhistidine, protein tags such as maltose-binding protein and glutathione- $S$-transferase, DNAdirected immobilization, and the biotin-streptavidin interaction pair. While highly useful, these approaches will not be discussed in this review. Instead, the reader is referred to excellent reviews published elsewhere ${ }^{2-7}$.

The present review focuses on covalent methods for site-specific protein immobilization. Covalent immobilization provides a distinct, more robust, and stable way of tethering proteins to a surface. Such modification of surfaces becomes important where more permanent properties are required, e.g. in medical sensors and implants. To a large extent, the advances made in this field represent implementations of developments in the more general field of site-specific protein modification. These developments comprise the discovery of new bioorthogonal reactions that proceed under physiological conditions between chemical groups that are absent in, and do not cross-react with, endogenous functionalities in proteins ${ }^{8,9}$. In addition, they include methods for the site-specific introduction of these bioorthogonal groups into proteins ${ }^{10}$. Worth mentioning, and potentially more appealing to researchers with a medical or biological background, are also the advances in the field of enzyme-mediated protein modification ${ }^{11,12}$.
Broadly speaking, we will highlight a selection of both enzymemediated and chemical approaches for covalent, site-specific protein immobilization. Illustrative examples from the past five years will be provided with the intention of demonstrating the intriguing diversity regarding the nature of the proteins, solid supports, and application purposes for which these approaches have been employed.

\section{Enzymatic approaches for covalent, site-specific protein immobilization}

Enzyme-mediated immobilization: sortase A

Sortase A is a transpeptidase from the Gram-positive bacterium Staphylococcus aureus that recognizes a LPXTG sequence at the $\mathrm{C}$-terminus of a target protein. Using a cysteine thiol nucleophile, it cleaves between the $\mathrm{T}$ and $\mathrm{G}$ residues of this sequence, yielding an acyl-enzyme intermediate. Subsequently, an N-terminal pentaglycine amine nucleophile attacks the thioester to complete the ligation reaction. The use of sortase for protein modification was introduced in $2007^{13,14}$. Since then, the approach has been exploited for a range of biotechnology applications including protein immobilization (see Figure 2 ) $^{15}$.

Recent examples of the use of sortase for site-specific protein immobilization include the conjugation of adhesion proteins to fluorescent microsphere beads ${ }^{16}$, the modification of liposomes with green fluorescent protein $(\mathrm{GFP})^{17}$, the production of an influenza virus protein array on glass slides ${ }^{18}$, antibody and enzyme immobilization on cellulose nanocrystals ${ }^{19}$, immobilization of a bait protein to agarose beads for application in affinity purification mass spectrometry ${ }^{20}$, and layer-by-layer immobilization of two fluorescent proteins on gold ${ }^{21}$. An interesting aspect of the lastmentioned study is the fact that two sortase variants were used with orthogonal substrate specificities. This facilitated the immobilization of GFP as the second protein layer on top of a layer of immobilized red fluorescent protein.

Sortase-mediated reactions reach a dynamic equilibrium because the reaction product is also a substrate for the enzyme. As a consequence, sortase-mediated reactions have low efficiency, and a large excess of both enzyme and substrate is required to obtain sufficient conversion. The reaction efficiency has been improved in different ways, amongst others by using a $\beta$-hairpin structure around the ligation site ${ }^{22}$ or depsipeptide substrates ${ }^{23}$. Both strategies prevent the reversible reaction from occurring. In addition, sortase variants with increased ligation activity have been evolved ${ }^{24}$.
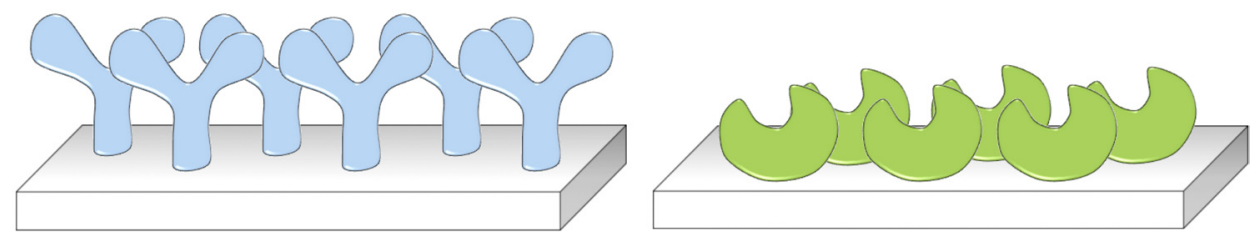

Figure 1. Schematic representation of oriented immobilization of (left) antibodies and (right) biocatalysts. Control over the site of immobilization ensures maximum accessibility to the analyte binding site and the biocatalyst's active site. 


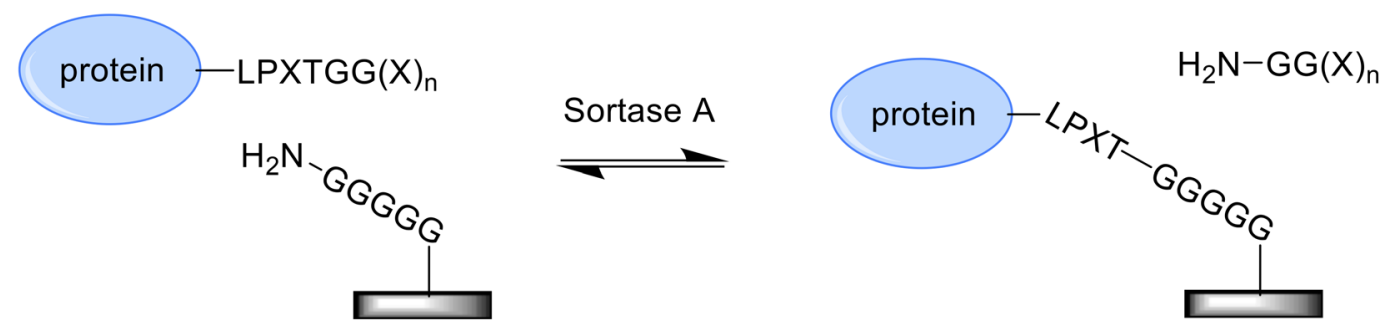

Figure 2. Sortase-mediated protein immobilization. Instead of pentaglycine, the solid support can be modified with substrate nucleophiles consisting of a smaller number of glycine residues. Alternatively, the LPXTG recognition sequence is coupled to the surface, and the protein of interest is tagged with an N-terminal oligoglycine motif.

Of particular interest in this context is the work by Heck et al. in which the authors developed an assay to follow the sortasemediated ligation on microparticles by real-time flow cytometry ${ }^{25}$. This assay allows for the comparison of different enzymatic (and chemical) immobilization strategies and the optimization of reaction parameters for enhanced immobilization performance.

The reversibility of the sortase-mediated reaction can be advantageous in applications in which the protein is denatured or deactivated over time. In such a case, sortase can be used for the regeneration of the bioactive surface, as demonstrated by Ham et $a l .{ }^{26}$. In addition, the reversibility of the reaction allows for the assessment of the degree of immobilization by cleaving the previously tethered protein followed by quantification using wellestablished solution-phase techniques. This approach was employed by Cambria et al. to determine the amount of immobilized human epidermal growth factor on functionalized hydrogels ${ }^{27}$.

Immobilization by an enzyme self-labeling tag: the SNAPtag

The SNAP-tag, which was first reported in 2003 by Keppler et al., is one of the most versatile self-labeling protein $\operatorname{tags}^{28}$. The protein, which is a mutant version of the human DNA repair protein $O^{6}$-alkylguanine-DNA-alkyltransferase (AGT), reacts with benzylguanine derivatives via an internal reactive cysteine residue, thereby forming a covalent thioether bond upon the release of guanine. In order to facilitate covalent, oriented protein immobilization, the SNAP-tag, which is $20 \mathrm{kDa}$ in size, is fused to a target protein, while the solid support is functionalized with a benzylguanine derivative (see Figure $3 \mathrm{~A})^{29}$.

In the past few years, the technology has been employed for the immobilization of GFP and extracellular fragments of the adhesion protein E-cadherin on gold surfaces containing a self-assembled monolayer of benzylguanine thiol mixed with methoxy-capped tri(ethylene glycol) undecanethiol ${ }^{30,31}$. Variation of the benzylguanine thiol concentration allowed for control over the protein density. The method was applied to investigate the adhesive functionality of E-cadherin surfaces by adhesion force spectroscopy. In a second example, SNAP-tagged fluorescent proteins and cadherin were coupled to quantum dots coated with amino-poly(ethylene glycol) and functionalized with an $\mathrm{N}$-Hydroxysuccinimide ester derivative of benzylguanine ${ }^{32}$. The fluorescent properties of the quantum dots and the model protein GFP enabled estimation of the immobilization efficiency. Recker et al. employed the SNAPtag technology for the immobilization of cytokines on polystyrene particles ${ }^{33}$. The directionally immobilized cytokines were shown to be fully signaling competent in cell culture, supporting the potential use of this approach for basic research on cytokine signal transduction and the improvement of biomaterials through functionalization with cytokines.

Additional examples of self-labeling protein tags include the HaloTag $(33 \mathrm{kDa})^{34}$ and the engineered variant of the SNAP-tag, CLIP-tag (see Figure 3B) $)^{35}$. Interestingly, the orthogonality in substrate specificity ( $O^{2}$-benzylcytosine vs. $O^{6}$-benzylguanine) allows for simultaneous and specific reaction of SNAP and CLIP fusion proteins with different molecular probes or, potentially, with positional control of immobilization on the same substrate surface.

\section{Chemical approaches for covalent, site-specific protein immobilization}

In the past few decades, several bioorthogonal chemistries have been developed for site-specific labeling of proteins and other biomolecules ${ }^{8,9}$. The development of these chemical reactions has greatly been driven by the desire to selectively label a target molecule in complex mixtures of biomolecules, such as cells or living organisms. In the following section, it will be shown how these bioorthogonal reactions can be very useful for the ligation of proteins in chemically less complicated media (that is, for immobilization purposes) as well.

The site-specific nature of these approaches depends on the fact that the functional groups which are employed in the different reactions are absent and do not cross-react with endogenous amino acids. Different site-specific methods can be used to introduce these groups into the protein of interest, after which the chemical immobilization reaction can occur. What is noteworthy is that the same method (for example, enzyme-mediated modification) has been used to introduce different functionalities (such as aldehydes, azides, or alkynes). This section is not meant to be exhaustive but rather describes a selection that, in our opinion, clearly demonstrates the value of the best chemical approaches for protein immobilization. A description of additional approaches, such as native chemical ligation, the Staudinger ligation, thiol-ene chemistry, photochemistry, and more specifically the combination of non-covalent 
a

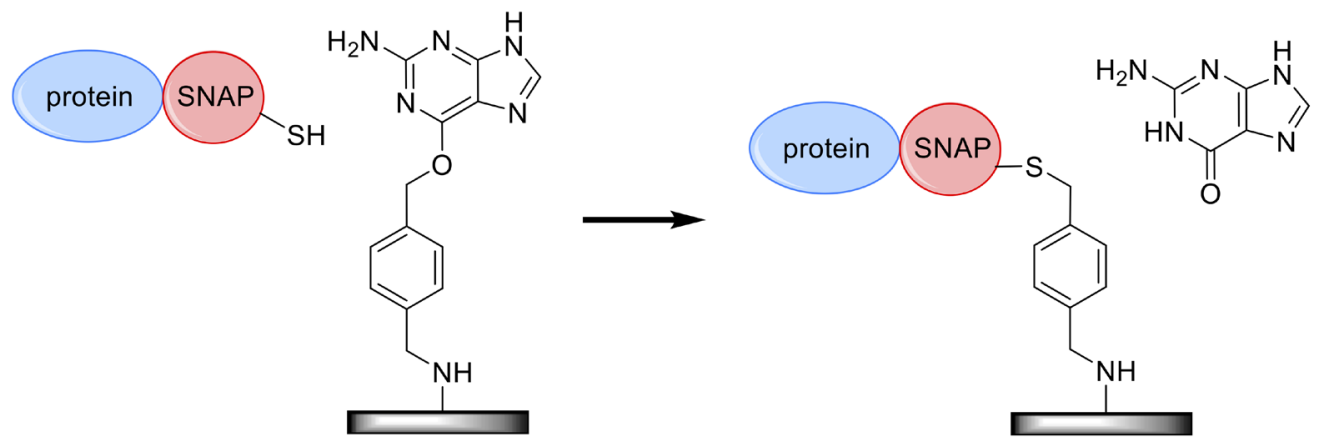

b

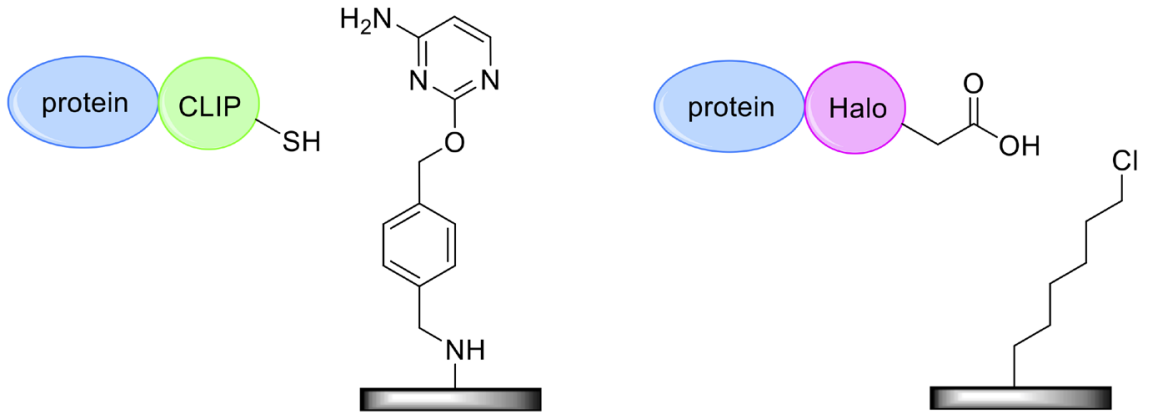

Figure 3. Site-specific protein immobilization by fusion to self-labeling tags. (a) The SNAP-tag, $20 \mathrm{kDa}$ in size, reacts with $\mathrm{O}^{6}$-benzylguanine. (b) The CLIP-tag (also $20 \mathrm{kDa}$ ) reacts with $\mathrm{O}^{2}$-benzylcytosine substrates, whereas the HaloTag (33 kDa) forms a covalent bond through nucleophilic displacement of halides from alkyl halide substrates.

interaction with photochemistry, can be found elsewhere ${ }^{1,36-39}$. An overview of the five elegant approaches discussed here is depicted in Figure 4.

\section{Oxime ligation}

The condensation of aldehydes or ketones with aminooxy or hydrazide compounds to give a stable oxime or hydrazone linkage, respectively, is known as the oxime ligation. The reaction is generally slow at neutral $\mathrm{pH}$ and is normally performed at $\mathrm{pH} 4-6$. The fact that neither the ketone/aldehyde nor the aminooxy/ hydrazide is naturally present in proteins makes this reaction ideal for oriented protein immobilization.

Ketones or aldehydes can be introduced into proteins in a sitespecific manner through the incorporation of non-natural amino acids, expressed protein ligation (EPL), or enzyme-mediated strategies $^{8}$. Additionally, the aldehyde or ketone moiety can be introduced by $\mathrm{N}$-terminal transamination, by periodate oxidation of an $\mathrm{N}$-terminal serine or threonine residue, or by periodate oxidation $^{40}$ or metabolic labeling ${ }^{41}$ of glycans in antibodies and other glycoproteins. Importantly, a recent advancement with respect to the oxime ligation (a reaction which itself has been known for decades) is the discovery that aniline can be used as a catalyst $^{42}$. It allows the reaction to be performed at neutral $\mathrm{pH}$, making it useful for $\mathrm{pH}$-sensitive proteins as well. However, it may be noted that oxime ligations are carried out under reversible conditions and although equilibrium is in strong favor of the product, oximes are prone to slow exchange reactions and hydrolysis. Therefore, in situations requiring high stability, the oxime or hydrazone bond is typically reduced with sodium cyanoborohydride.

Cho et al. reported one of the latest examples utilizing the oxime ligation for oriented protein immobilization. Two enzymes, alkaline phosphatase and methyltryptophan oxidase, were tethered to amine-coated beads and similarly coated surfaces of a 96-well plate $^{43}$. In order to introduce the aldehyde moiety into these model proteins, the researchers utilized formylglycinegenerating enzyme, which is known to oxidize the cysteine of a six-amino-acid recognition sequence. This ligation was stabilized by oxime reduction ${ }^{4}$.

In other applications, however, the reversible nature of the oxime ligation can be exploited. Rashidian et al. describe the chemoenzymatic, reversible immobilization of GFP and the therapeutic protein glucose-dependent insulinotropic polypeptide. Protein farnesyl transferase (PFTase) was used for the introduction of the aldehyde moiety ${ }^{45}$. Interestingly, the proteins, containing a $\mathrm{C}$-terminal tetrapeptide as the PFTase recognition sequence, could be captured selectively from a crude cellular extract. After coupling to hydrazide-modified agarose beads, the proteins were released under mild conditions by the addition of an alkoxyamine. The use of synthetically modified alkoxyamines, containing a fluorophore or a PEG chain, allowed for the simultaneous modification of the purified proteins. 
a

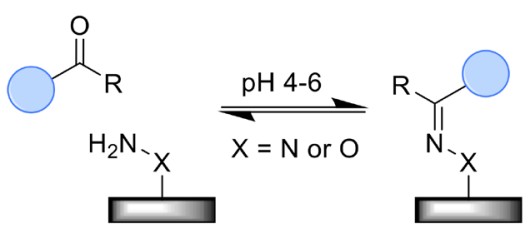

b

C

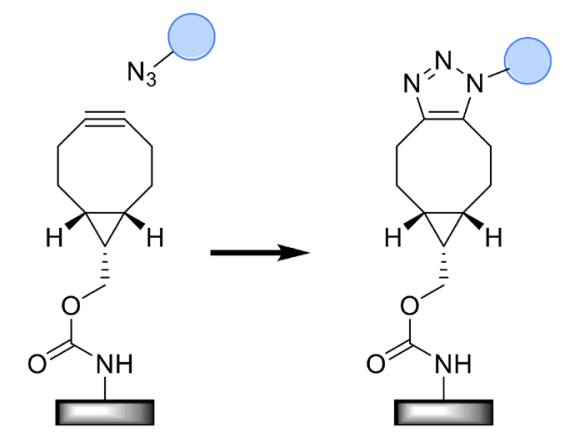

d

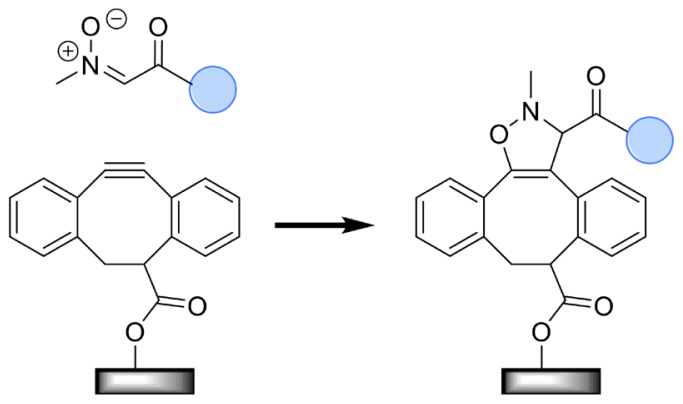

e

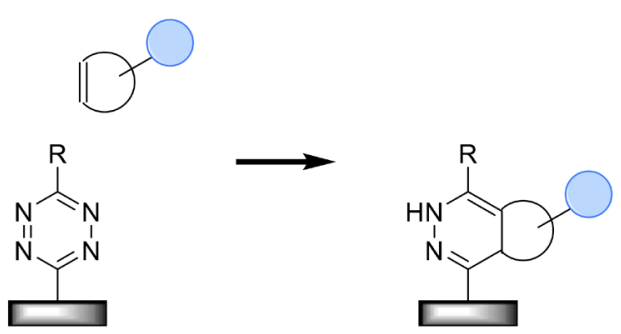

Figure 4. Selection of chemical approaches for covalent, site-specific immobilization of proteins. (a) Oxime ligation, (b) Cu(I)-catalyzed azide-alkyne cycloaddition (CuAAC) reaction, (c) strain-promoted azide-alkyne cycloaddition (SPAAC) reaction, (d) strain-promoted alkynenitrone cycloaddition (SPANC) reaction, and (e) inverse electron-demand Diels-Alder reaction (IEDDA) reaction.

\section{Azide-alkyne cycloaddition}

The 1,3-dipolar cycloaddition between azides and alkynes is one of the best-known click reactions ${ }^{46-48}$. Essential for its popularity has been the discovery by both the Meldal and Sharpless research groups that the reaction proceeds at room temperature if $\mathrm{Cu}(\mathrm{I})$ is used as the catalyst ${ }^{49-51}$. The reaction has found widespread use in a myriad of applications, including the investigation and manipulation of proteins ${ }^{52-55}$. Also for protein immobilization, the $\mathrm{Cu}(\mathrm{I})$-catalyzed azide-alkyne cycloaddition $(\mathrm{CuAAC})$ and its strain-promoted variant (SPAAC) ${ }^{56}$ have become more and more popular. Like aldehydes and ketones, azides and alkynes are not naturally present in proteins and thus have to be introduced using either a biosynthetic or a chemical approach.

The incorporation of non-natural amino acids, in particular, has been shown to be an attractive approach. Both site-specific introduction using the amber suppression method ${ }^{57}$ and the more straightforward approach of residue-specific replacement ${ }^{58}$ have been employed for this purpose. For example, an engineered variant of GFP, functionalized with a single azide by expression in an auxotrophic bacteria strain using azidonorleucine as a methionine surrogate, was immobilized on SPR sensor surfaces via the SPAAC reaction $^{59}$. The same protein, site-specifically functionalized via genetic encoding of a cyclooctyne-containing amino acid, was used to demonstrate the use of the SPAAC reaction in biomolecular patterning of glass surfaces ${ }^{60}$. In this proof-of-concept study, the increase in fluorescence of azidocoumarin-modified glass upon reaction with a cyclooctyne provided a convenient read-out of the immobilization process.

GFP also acted as the model protein in an interesting study in which the effect of the type of solid support, the linker length, and the immobilization site on CuAAC-mediated immobilization efficiency was investigated ${ }^{61}$. For this purpose, the amber suppression method was utilized to facilitate the introduction of paraazidophenylalanine at three different positions in the protein. Polystyrene, TentaGel - consisting of poly(styrene-oxyethylene) graft copolymer - and Sepharose (cross-linked agarose) resins 
were selected as solid supports. Sepharose derivatized with propargyl alcohol afforded the highest yield of immobilization. Up to 2-fold difference in immobilization efficiency was observed depending on the location of the clickable handle.

Trilling et al. combined non-natural amino acid incorporation with the SPAAC reaction for oriented immobilization of antibody fragments ${ }^{62}$. The variable domain of a llama antibody was functionalized with a single azidohomoalanine residue and coupled to a bicyclononyne-modified SPR chip. It was shown that the oriented immobilization led to a strongly increased sensitivity of the biosensor when compared to an SPR chip containing randomly immobilized antibodies. More recently, Lühmann et al. demonstrated the site-specific conjugation of fibroblast growth factor 2 to agarose beads through genetic encoding of propargyl-lysine followed by the CuAAC reaction ${ }^{63}$. The immobilized growth factor was shown to have retained its ability to induce cell proliferation. Of interest for the field of biocatalysis is the study reported by $\mathrm{Wu}$ et al. The model enzyme T4 lysozyme was immobilized on superparamagnetic beads ${ }^{64}$. Site-specific, CuAAC-mediated immobilization enhanced the stability of the enzymes towards freeze-thaw cycles and the denaturant urea when compared to enzyme immobilized in a random manner on epoxy-modified beads. The activity of the immobilized enzyme was shown to vary depending on the site of conjugation.

Instead of non-natural amino acid incorporation, EPL can facilitate $\mathrm{N}$ - or C-terminus-specific functionalization of proteins with azides or alkyne moieties ${ }^{65-67}$. The method has been combined with the azide-alkyne cycloaddition, amongst others, to immobilize GFP and aldo-keto reductase on a PEG-based solid support ${ }^{68}$, GFP and single-chain variable fragment antibodies on agarose beads ${ }^{69}$, and nanobodies on polymersome vesicles ${ }^{70}$. A HER2 affibody, a $6.5 \mathrm{kDa}$ protein with high affinity for the oncogene HER2/neu receptor, has been tethered to superparamagnetic iron oxide (SPIO) nanoparticles ${ }^{71}$. This approach was used to target the nanoparticles, acting as imaging agents, to tumor cells. What is noteworthy is that these HER2-SPIO nanoparticles, obtained by the combination of EPL and CuAAC chemistry, were shown to perform better than SPIO nanoparticles to which the same affibody was conjugated using random immobilization approaches.

As a third approach, enzymes have been employed for the introduction of azides and alkynes into proteins. For example, Keillor and colleagues showed that microbial transglutaminase is able to catalyze the attachment of propargyl amine to the C-terminus of proteins $^{72}$. A heptapeptide, also called Q-tag, functioned as the recognition sequence. In a proof-of-principle experiment, a Q-tagged fluorescent protein was immobilized to magnetic azide-modified nanoparticles using the CuAAC reaction as the conjugation method. Moreover, Qu et al. combined enzymatic modification with the SPAAC reaction for the immobilization of thrombomodulin ${ }^{73}$. Sortase A was employed to introduce an azide moiety at the C-terminus of this blood-coagulation-reducing protein. Subsequently, the protein was tethered to dibenzocyclooctyne-modified vascular grafts, which were thus rendered thromboresistant. Interestingly, it was shown that the dibenzocyclooctyne-modified surfaces could be sterilized by ethylene oxide prior to the strain-promoted $[3+2]$ cycloaddition. In this way, the described strategy has great potential for clinical application by providing a sterile off-the-shelf product ready to be coated with azide-modified therapeutic protein right before implantation.

As a chemical alternative to the abovementioned biosynthetic methods, we recently showed that a single azide can be sitespecifically introduced at the N-terminus of GFP using the $\mathrm{pH}$-controlled and metal-free diazo transfer reaction ${ }^{74}$. This straightforward procedure was combined with the SPAAC reaction to immobilize azido-functionalized GFP on bicyclooctynemodified vertical GaAs nanowires ${ }^{75}$. It was shown by fluorescence microscopy that anti-GFP antibody bound to the immobilized protein. The experiment functioned as a proof-of-concept study, demonstrating the feasibility of functionalizing vertical semiconductor nanowires for biological applications, such as biosensing and the study of protein-protein interactions.

\section{Other click reactions}

In 2010, the need for a bioorthogonal reaction faster than SPAAC for the labeling of proteins in living systems led to the development of the strain-promoted alkyne-nitrone cycloaddition (SPANC) ${ }^{76}$. The 1,3-dipole nitrone is used as a more reactive alternative for an azide, leading to reaction rates that are up to 30 times faster. Despite the fact that its use for protein labeling in general has been limited so far, the reaction has already been successfully applied for protein immobilization. Single-chain variable fragment antibodies against the tumor marker HER2 were coupled to fluorescent, superparamagnetic nanoparticles ${ }^{77}$. The nitrone group was introduced specifically at the N-terminus of the antibody molecules. Binding of the targeted nanoparticles to HER2-positive cells was observed, demonstrating the feasibility of the approach and its potential use as a general strategy for the development of a new generation of targeted nanoparticles.

The inverse electron-demand Diels-Alder reaction (IEDDA) between 1,2,4,5-tetrazines and strained alkenes or alkynes is another click reaction that was recently introduced ${ }^{78}$. Especially, when trans-cyclooctene is used as the strained alkene, the reaction rate is extremely high, exceeding those of the SPAAC, SPANC, and $\mathrm{CuAAC}$ reactions ${ }^{79}$. However, speed and concomitantly lower usable reagent concentrations are typically of less importance in the case of protein immobilization. Researchers have, nevertheless, explored the use of the IEDDA reaction for this application ${ }^{80-82}$. So far, though, the method has been used only in a non-specific manner by functionalizing the proteins of interest with an NHSderivative of tetrazine or trans-cyclooctene. Non-natural amino acids bearing various strained alkenes, alkynes, and tetrazine have been synthesized and can now be incorporated into proteins in a site-specific manner ${ }^{83-85}$. Therefore, it is expected that the first reports employing the IEDDA reaction for oriented protein immobilization will appear in the near future.

\section{Concluding remarks}

In conclusion, we believe that the large set of methods available today to site-specifically immobilize proteins to solid supports holds great promise for future use in applications ranging from biosensor development to biocatalyst immobilization and 
next-generation biomaterials. A considerable number of examples performed on a diverse set of proteins and solid supports has been provided that substantiate this prospect. Particularly exciting are those studies that are close to a final application, such as the thrombomodulin-modified vascular grafts ${ }^{73}$. An important note is that several more or fewer orthogonal click reactions have appeared over recent years that in years to come will allow us to carry out macrostructured immobilization of a range of functional proteins working in concert.

Unfortunately, most reports deal with proof-of-concept studies and only in a few cases has the immobilization efficiency been addressed. Therefore, it is currently difficult to compare the different approaches and to select the optimal method for a specific application. In our opinion, it would be extremely interesting if more analytical studies would be performed such as the one reported by Heck et al., comparing the ligation efficiency of several sortase variants ${ }^{25}$. Of interest is also the kind of analysis performed by Lühmann et al. ${ }^{63}$, in which the immobilization efficiency was estimated as the fraction of bound protein relative to the total amount of protein used. The more common measure of expressing the yield as the fraction of surface that got covered ${ }^{20,32,33}$ does not provide any information on the amount of protein that was lost during the immobilization process. This information will be valuable from an economical point of view and when protein availability is limited, for example because of low expression yields, often associated with less stable and more interesting proteins. It should be noted that regarding the surface coverage, it is the fraction of active protein molecules that is most relevant. When proteins other than fluorescent proteins are immobilized, such analysis will obviously be more challenging. The control of surface density is another aspect that has received little attention so far. This feature can be controlled in the primary functionalization step in which the surface is efficiently and stably modified with, for example, azide or alkyne groups for the $\mathrm{CuAAC}$ or SPAAC reaction ${ }^{75}$ or pentaglycine or benzylguanine for sortase- or SNAP-tag-mediated protein immobilization, respectively ${ }^{15,29}$. As described above, Fichtner et al. used such an approach to vary the density of adhesion protein on gold surfaces $^{31}$.

Undoubtedly, it is not only the efficiency of the immobilization strategy that plays a role in the selection process. Another decisive factor is the freedom in selecting the site of conjugation, which is highest in the case of the chemical approaches combining nonnatural amino acid incorporation with one of the click reactions. Low stability and sensitivity of the protein to low $\mathrm{pH}$ or towards an organic or metal catalyst will point to one of the newest click reactions such as SPAAC, SPANC, and IEDDA. However, one should be aware of the hydrophobicity of the functionalities involved in these reactions, which may lead to incompatibilities and inefficient conjugation ${ }^{86}$. Expression yields are generally lower when non-natural amino acids are incorporated. While studies are ongoing to improve these yields (as exemplified by the work of Schmied et $a l^{87}$ ), this fact supports the relevance of measuring the fraction of immobilized protein, i.e. the yield of reaction (loss of protein) at a given protein concentration.

For researchers with limited expertise regarding synthesis and surface modification with, for example, strained alkynes and tetrazines, enzymatic strategies will often be appealing. An important advantage of the last-mentioned methods is the fact that the protein can be produced under native conditions, providing lower costs and higher yields compared to the strategies involving nonnatural amino acid incorporation. In such ligations, however, an enzyme recognition sequence or enzyme tag will always need to be added to the protein.

\section{Competing interests}

The authors declare that they have no competing interests.

\section{Grant information}

The authors acknowledge the Danish Council for Independent Research and the European Commission (DFF Mobilex grant 4093-00083) for financial support.
1. Berrade L, Garcia AE, Camarero JA: Protein microarrays: novel developments and applications. Pharm Res. 2011; 28(7): 1480-99. PubMed Abstract | Publisher Full Text | Free Full Text

2. Steen Redeker E, Ta DT, Cortens D, et al:: Protein engineering for directed immobilization. Bioconjug Chem. 2013; 24(11): 1761-77. PubMed Abstract | Publisher Full Text

3. F Liu YS, Yu J: Oriented immobilization of proteins on solid supports for use in biosensors and biochips: a review. Microchim Acta. 2016; 183: 1-19. Publisher Full Text | F1000 Recommendation

4. Sapsford KE, Algar WR, Berti L, et al.: Functionalizing nanoparticles with biological molecules: developing chemistries that facilitate nanotechnology. Chem Rev. 2013; 113(3): 1904-2074. PubMed Abstract | Publisher Full Text

5. Benešová E, Králová B: Affinity Interactions as a Tool for Protein Immobilization. In: Magdeldin S, editor. Affinity Chromatography: InTech. 2012; $29-46$. Publisher Full Text

6. Trilling AK, Beekwilder J, Zuilhof $\mathrm{H}$ : Antibody orientation on biosensor surfaces: a minireview. Analyst. 2013; 138(6): 1619-27.

PubMed Abstract | Publisher Full Text
7. Meyer R, Giselbrecht S, Rapp BE, et al:: Advances in DNA-directed immobilization. Curr Opin Chem Biol. 2014; 18: 8-15. PubMed Abstract | Publisher Full Text

8. F McKay CS, Finn MG: Click chemistry in complex mixtures: bioorthogonal bioconjugation. Chem Biol. 2014; 21(9): 1075-101.

PubMed Abstract | Publisher Full Text | Free Full Text | F1000 Recommendation

9. Sletten EM, Bertozzi CR: Bioorthogonal chemistry: fishing for selectivity in a sea of functionality. Angew Chem Int Ed Engl. 2009; 48(38): 6974-98. PubMed Abstract | Publisher Full Text | Free Full Text

10. F Lang K, Chin JW: Cellular incorporation of unnatural amino acids and bioorthogonal labeling of proteins. Chem Rev. 2014; 114(9): 4764-806. PubMed Abstract | Publisher Full Text | F1000 Recommendation

11. Matsumoto T, Tanaka T, Kondo A: Enzyme-mediated methodologies for protein modification and bioconjugate synthesis. Biotechnol J. 2012; 7(9): 1137-46. PubMed Abstract | Publisher Full Text

12. F Walper SA, Turner KB, Medintz IL: Enzymatic bioconjugation of nanoparticles: developing specificity and control. Curr Opin Biotechnol. 2015; 34: 232-41.

PubMed Abstract | Publisher Full Text | F1000 Recommendation

13. Popp MW, Antos JM, Grotenbreg GM, et al:: Sortagging: a versatile method for 
protein labeling. Nat Chem Biol. 2007; 3(11): 707-8.

PubMed Abstract | Publisher Full Text

14. Parthasarathy R, Subramanian S, Boder ET: Sortase A as a novel molecular "stapler" for sequence-specific protein conjugation. Bioconjug Chem. 2007; 18(2): 469-76.

PubMed Abstract | Publisher Full Text

15. Proft T: Sortase-mediated protein ligation: an emerging biotechnology tool for protein modification and immobilisation. Biotechnol Lett. 2010; 32(1): 1-10. PubMed Abstract | Publisher Full Text

16. Wu S, Proft $\mathrm{T}$ : The use of sortase-mediated ligation for the immobilisation of bacterial adhesins onto fluorescence-labelled microspheres: a novel approach to analyse bacterial adhesion to host cells. Biotechnol Lett. 2010; 32(11): 1713-8. PubMed Abstract | Publisher Full Text

17. Guo X, Wu Z, Guo Z: New method for site-specific modification of liposomes with proteins using sortase A-mediated transpeptidation. Bioconjug Chem. 2012; 23(3): 650-5

PubMed Abstract | Publisher Full Text | Free Full Text

18. Sinisi A, Popp MW, Antos JM, et al.: Development of an influenza virus protein array using Sortagging technology. Bioconjug Chem. 2012; 23(6): 1119-26. PubMed Abstract | Publisher Full Text | Free Full Text

19. F Uth C, Zielonka S, Hörner S, et al.: A chemoenzymatic approach to protein immobilization onto crystalline cellulose nanoscaffolds. Angew Chem Int Ed Engl. 2014; 53(46): 12618-23.

PubMed Abstract | Publisher Full Text | F1000 Recommendation

20. F Kuropka B, Royla N, Freund C, et al:: Sortase A mediated site-specific immobilization for identification of protein interactions in affinity purificationmass spectrometry experiments. Proteomics. 2015; 15(7): 1230-4. PubMed Abstract | Publisher Full Text | F1000 Recommendation

21. F Raeeszadeh-Sarmazdeh M, Parthasarathy R, Boder ET: Site-specific immobilization of protein layers on gold surfaces via orthogonal sortases. Colloids Surf B Biointerfaces. 2015; 128: 457-63.

PubMed Abstract | Publisher Full Text | F1000 Recommendation

22. Yamamura $\mathrm{Y}$, Hirakawa $\mathrm{H}$, Yamaguchi S, et al.: Enhancement of sortase Amediated protein ligation by inducing a $\beta$-hairpin structure around the ligation site. Chem Commun (Camb). 2011; 47(16): 4742-4.

PubMed Abstract | Publisher Full Text

23. Williamson DJ, Fascione MA, Webb ME, et al:: Efficient N-terminal labeling of proteins by use of sortase. Angew Chem Int Ed Engl. 2012; 51(37): 9377-80. PubMed Abstract | Publisher Full Text

24. F Chen I, Dorr BM, Liu DR: A general strategy for the evolution of bondforming enzymes using yeast display. Proc Natl Acad Sci U S A. 2011; 108(28): 11399-404.

PubMed Abstract | Publisher Full Text | Free Full Text | F1000 Recommendation

25. F Heck T, Pham P, Hammes F, et al.: Continuous monitoring of enzymatic reactions on surfaces by real-time flow cytometry: sortase a catalyzed protein immobilization as a case study. Bioconjug Chem. 2014; 25(8): 1492-500. PubMed Abstract | Publisher Full Text | F1000 Recommendation

26. F Ham HO, Qu Z, Haller CA, et al.: In situ regeneration of bioactive coatings enabled by an evolved Staphylococcus aureus sortase A. Nat Commun. 2016; 7: 11140.

PubMed Abstract | Publisher Full Text | Free Full Text | F1000 Recommendation

27. F Cambria E, Renggli K, Ahrens CC, et al:: Covalent Modification of Synthetic Hydrogels with Bioactive Proteins via Sortase-Mediated Ligation. Biomacromolecules. 2015; 16(8): 2316-26.

PubMed Abstract | Publisher Full Text | Free Full Text | F1000 Recommendation

28. F Keppler A, Gendreizig S, Gronemeyer T, et al: A general method for the covalent labeling of fusion proteins with small molecules in vivo. Nat Biotechnol. 2003; 21(1): 86-9.

PubMed Abstract | Publisher Full Text | F1000 Recommendation

29. Engin S, Fichtner D, Wedlich D, et al:: SNAP-tag as a tool for surface immobilization. Curr Pharm Des. 2013; 19(30): 5443-8. PubMed Abstract | Publisher Full Text

30. Engin S, Trouillet V, Franz CM, et al:: Benzylguanine thiol self-assembled monolayers for the immobilization of SNAP-tag proteins on microcontactprinted surface structures. Langmuir. 2010; 26(9): 6097-101. PubMed Abstract | Publisher Full Text

31. F Fichtner D, Lorenz B, Engin S, et al:: Covalent and density-controlled surface immobilization of E-cadherin for adhesion force spectroscopy. PLOS One. 2014; 9(3): e93123.

PubMed Abstract | Publisher Full Text | Free Full Text | F1000 Recommendation

32. Petershans A, Wedlich D, Fruk L: Bioconjugation of CdSe/ZnS nanoparticles with SNAP tagged proteins. Chem Commun (Camb). 2011; 47(38): 10671-3. PubMed Abstract | Publisher Full Text

33. Recker T, Haamann D, Schmitt A, et al: Directed covalent immobilization of fluorescently labeled cytokines. Bioconjug Chem. 2011; 22(6): 1210-20. PubMed Abstract | Publisher Full Text

34. Los GV, Encell LP, McDougall MG, et al:: HaloTag: a novel protein labeling technology for cell imaging and protein analysis. ACS Chem Biol. 2008; 3(6): 373-82.

PubMed Abstract | Publisher Full Text
35. F Gautier A, Juillerat A, Heinis $\mathrm{C}$, et al:: An engineered protein tag for multiprotein labeling in living cells. Chem Biol. 2008; 15(2): 128-36. PubMed Abstract | Publisher Full Text | F1000 Recommendation

36. Chen YX, Triola G, Waldmann H: Bioorthogonal chemistry for site-specific labeling and surface immobilization of proteins. Acc Chem Res. 2011; 44(9): 762-73.

PubMed Abstract | Publisher Full Text

37. Gori A, Longhi R: Chemoselective Strategies to Peptide and Protein Bioprobes Immobilization on Microarray Surfaces. Methods Mol Biol. 2016; 1352: 145-56. PubMed Abstract | Publisher Full Text

38. Jonkheijm $\mathrm{P}$, Weinrich $\mathrm{D}$, Schröder $\mathrm{H}$, et al.: Chemical strategies for generating protein biochips. Angew Chem Int Ed Engl. 2008; 47(50): 9618-47. PubMed Abstract | Publisher Full Text

39. Hui JZ, Tamsen S, Song Y, et al:: LASIC: Light Activated Site-Specific Conjugation of Native IgGs. Bioconjug Chem. 2015; 26(8): 1456-60. PubMed Abstract | Publisher Full Text

40. Sorci M, Dassa B, Liu H, et al: Oriented covalent immobilization of antibodies for measurement of intermolecular binding forces between zipper-like contact surfaces of split inteins. Anal Chem. 2013; 85(12): 6080-8.

PubMed Abstract | Publisher Full Text | Free Full Text

41. Mahal LK, Yarema KJ, Bertozzi CR: Engineering chemical reactivity on cell surfaces through oligosaccharide biosynthesis. Science. 1997; 276(5315): $1125-8$

PubMed Abstract | Publisher Full Text

42. Dirksen A, Hackeng TM, Dawson PE: Nucleophilic catalysis of oxime ligation. Angew Chem Int Ed Engl. 2006; 45(45): 7581-4. PubMed Abstract | Publisher Full Text

43. $\mathrm{F}$ Cho H, Jaworski J: Enzyme directed formation of un-natural side-chains for covalent surface attachment of proteins. Colloids Surf B Biointerfaces. 2014 122: $846-50$.

PubMed Abstract | Publisher Full Text | F1000 Recommendation

44. F Carrico IS, Carlson BL, Bertozzi CR: Introducing genetically encoded aldehydes into proteins. Nat Chem Biol. 2007; 3(6): 321-2. PubMed Abstract | Publisher Full Text | F1000 Recommendation

45. F Rashidian M, Song JM, Pricer RE, et al:: Chemoenzymatic reversible immobilization and labeling of proteins without prior purification. J Am Chem Soc. 2012; 134(20): 8455-67.

PubMed Abstract | Publisher Full Text | Free Full Text | F1000 Recommendation

46. Meldal M, Tornøe CW: Cu-catalyzed azide-alkyne cycloaddition. Chem Rev. 2008; 108(8): 2952-3015.

PubMed Abstract | Publisher Full Text

47. Trost BM, Li C: Modern alkyne chemistry: Catalytic and atom-economic transformations. Edited by Barry M. Trost and Chao-Jun Li. Publisher Full Text

48. Kolb HC, Sharpless KB: The growing impact of click chemistry on drug discovery. Drug Discov Today. 2003; 8(24): 1128-37. PubMed Abstract | Publisher Full Text

49. Lebl M, Houghten RA: Peptides: The wave of the future. Proceedings of the Second International and the Seventeenth American Peptide Symposium, June 9-14, 2001, San Diego, California, U.S.A. Dordrecht: Springer; 2001; 7. Publisher Full Text

50. Tornøe CW, Christensen C, Meldal M: Peptidotriazoles on solid phase: $[1,2,3]-$ triazoles by regiospecific copper(i)-catalyzed 1,3-dipolar cycloadditions of terminal alkynes to azides. J Org Chem. 2002; 67(9): 3057-64. PubMed Abstract | Publisher Full Text

51. Rostovtsev VV, Green LG, Fokin VV, et al.: A stepwise huisgen cycloaddition process: copper(I)-catalyzed regioselective "ligation" of azides and terminal alkynes. Angew Chem Int Ed Engl. 2002; 41(14): 2596-9. PubMed Abstract | Publisher Full Text

52. Palomo JM: Click reactions in protein chemistry: from the preparation of semisynthetic enzymes to new click enzymes. Org Biomol Chem. 2012; 10(47): 9309-18.

PubMed Abstract | Publisher Full Text

53. Lallana E, Riguera R, Fernandez-Megia E: Reliable and efficient procedures for the conjugation of biomolecules through Huisgen azide-alkyne cycloadditions. Angew Chem Int Ed Engl. 2011; 50(38): 8794-804. PubMed Abstract | Publisher Full Text

54. Thirumurugan $\mathrm{P}$, Matosiuk $\mathrm{D}$, Jozwiak $\mathrm{K}$ : Click chemistry for drug development and diverse chemical-biology applications. Chem Rev. 2013; 113(7): 4905-79. PubMed Abstract | Publisher Full Text

55. Jewett JC, Bertozzi CR: Cu-free click cycloaddition reactions in chemical biology. Chem Soc Rev. 2010; 39(4): 1272-9. PubMed Abstract | Publisher Full Text | Free Full Text

56. F Agard NJ, Prescher JA, Bertozzi CR: A strain-promoted [3 + 2] azide-alkyne cycloaddition for covalent modification of biomolecules in living systems. J Am Chem Soc. 2004; 126(46): 15046-7.

PubMed Abstract | Publisher Full Text | F1000 Recommendation

57. Liu CC, Schultz PG: Adding new chemistries to the genetic code. Annu Rev Biochem. 2010: 79: 413-44.

PubMed Abstract | Publisher Full Text 
58. Johnson JA, Lu YY, Van Deventer JA, et al:: Residue-specific incorporation of non-canonical amino acids into proteins: recent developments and applications. Curr Opin Chem Biol. 2010; 14(6): 774-80. PubMed Abstract | Publisher Full Text | Free Full Text

59. Wammes AE, Fischer MJ, de Mol NJ, et al.: Site-specific peptide and protein immobilization on surface plasmon resonance chips via strain-promoted cycloaddition. Lab Chip. 2013; 13(10): 1863-7.

PubMed Abstract | Publisher Full Text

60. Wijdeven MA, Nicosia C, Borrmann A, et al:: Biomolecular patterning of glass surfaces via strain-promoted cycloaddition of azides and cyclooctynes. RSC Adv. 2014; 4(21): 10549-10552.

Publisher Full Text

61. F Raliski BK, Howard CA, Young DD: Site-specific protein immobilization using unnatural amino acids. Bioconjug Chem. 2014; 25(11): 1916-20. PubMed Abstract | Publisher Full Text | F1000 Recommendation

62. Trilling AK, Hesselink T, van Houwelingen A, et al:: Orientation of Ilama antibodies strongly increases sensitivity of biosensors. Biosens Bioelectron 2014; 60: 130-6.

PubMed Abstract | Publisher Full Text

63. F Lühmann T, Jones G, Gutmann M, et al:: Bio-orthogonal immobilization of fibroblast growth factor $\mathbf{2}$ for spatial controlled cell proliferation. ACS Biomater Sci Eng. 2015; 1(9): 740-746.

Publisher Full Text | F1000 Recommendation

64. $\mathrm{F}$ Wu JC, Hutchings $\mathrm{CH}$, Lindsay MJ, et al:: Enhanced enzyme stability through site-directed covalent immobilization. J Biotechnol. 2015; 193: 83-90. PubMed Abstract | Publisher Full Text | F1000 Recommendation

65. Lin PC, Ueng SH, Tseng MC, et al:: Site-specific protein modification through Cu'-catalyzed 1,2,3-triazole formation and its implementation in protein microarray fabrication. Angew Chem Int Ed Engl. 2006; 45(26): 4286-90. PubMed Abstract | Publisher Full Text

66. Kalia J, Raines RT: Reactivity of intein thioesters: appending a functional group to a protein. Chembiochem. 2006; 7(9): 1375-83. PubMed Abstract | Publisher Full Text

67. F Xiao J, Tolbert TJ: Synthesis of $\mathrm{N}$-terminally linked protein dimers and trimers by a combined native chemical ligation-CuAAC click chemistry strategy. Org Lett. 2009; 11(18): 4144-7.

PubMed Abstract | Publisher Full Text | F1000 Recommendation

68. Steinhagen M, Holland-Nell K, Meldal M, et al.: Simultaneous "one pot" expressed protein ligation and Cu'-catalyzed azide/alkyne cycloaddition for protein immobilization. Chembiochem. 2011; 12(16): 2426-30. PubMed Abstract | Publisher Full Text

69. Marshall CJ, Agarwal N, Kalia J, et al:: Facile chemical functionalization of proteins through intein-linked yeast display. Bioconjug Chem. 2013; 24(9): 1634-44.

PubMed Abstract | Publisher Full Text | Free Full Text

70. Debets MF, Leenders WP, Verrijp K, et al:: Nanobody-functionalized polymersomes for tumor-vessel targeting. Macromol Biosci. 2013; 13(7): 938-45. PubMed Abstract | Publisher Full Text

71. F Elias DR, Cheng Z, Tsourkas A: An intein-mediated site-specific click conjugation strategy for improved tumor targeting of nanoparticle systems. Small. 2010; 6(21): 2460-8.

PubMed Abstract | Publisher Full Text | Free Full Text | F1000 Recommendation

72. F Oteng-Pabi SK, Pardin C, Stoica M, et al.: Site-specific protein labelling and immobilization mediated by microbial transglutaminase. Chem Commun (Camb). 2014; 50(50): 6604-6.

PubMed Abstract | Publisher Full Text | F1000 Recommendation
73. F Qu Z, Krishnamurthy V, Haller CA, et al.: Immobilization of actively thromboresistant assemblies on sterile blood-contacting surfaces. Adv Healthc Mater. 2014; 3(1): 30-5

PubMed Abstract | Publisher Full Text | Free Full Text | F1000 Recommendation

74. Schoffelen S, van Eldijk MB, Rooijakkers B, et al.: Metal-free and pH-controlled introduction of azides in proteins. Chem Sci. 2011; 2(4): 701-705. Publisher Full Text

75. Vutti S, Schoffelen S, Bolinsson J, et al.: Click Chemistry Mediated Functionalization of Vertical Nanowires for Biological Applications. Chemistry. 2016; 22(2): 496-500. PubMed Abstract | Publisher Full Text

76. F Ning X, Temming RP, Dommerholt J, et al:: Protein modification by strainpromoted alkyne-nitrone cycloaddition. Angew Chem Int Ed Engl. 2010; 49(17): 3065-8.

PubMed Abstract | Publisher Full Text | Free Full Text | F1000 Recommendation

77. Colombo M, Sommaruga S, Mazzucchelli S, et al: Site-specific conjugation of ScFvs antibodies to nanoparticles by bioorthogonal strain-promoted alkynenitrone cycloaddition. Angew Chem Int Ed Engl. 2012; 51(2): 496-9. PubMed Abstract | Publisher Full Text

78. F Blackman ML, Royzen M, Fox JM: Tetrazine ligation: fast bioconjugation based on inverse-electron-demand Diels-Alder reactivity. J Am Chem Soc. 2008; 130(41): 13518-9.

PubMed Abstract | Publisher Full Text | Free Full Text | F1000 Recommendation

79. Lang K, Chin JW: Bioorthogonal reactions for labeling proteins. ACS Chem Biol. 2014; 9(1): 16-20. PubMed Abstract | Publisher Full Text

80. Han H, Devaraj NK, Lee J, et al.: Development of a bioorthogonal and highly efficient conjugation method for quantum dots using tetrazine-norbornene cycloaddition. J Am Chem Soc. 2010; 132(23): 7838-9. PubMed Abstract | Publisher Full Text | Free Full Text

81. Haun JB, Devaraj NK, Marinelli BS, et al.: Probing intracellular biomarkers and mediators of cell activation using nanosensors and bioorthogonal chemistry. ACS Nano. 2011; 5(4): 3204-13.

PubMed Abstract | Publisher Full Text | Free Full Text

82. Han HS, Niemeyer E, Huang $\mathrm{Y}$, et al.: Quantum dot/antibody conjugates for in vivo cytometric imaging in mice. Proc Natl Acad Sci U S A. 2015; 112(5): 1350-5. PubMed Abstract | Publisher Full Text | Free Full Text

83. Borrmann A, Milles S, Plass T, et al.: Genetic encoding of a bicyclo[6.1.0]nonyne-charged amino acid enables fast cellular protein imaging by metal-free ligation. Chembiochem. 2012; 13(14): 2094-9. PubMed Abstract | Publisher Full Text

84. Plass T, Milles S, Koehler C, et al:: Amino acids for Diels-Alder reactions in living cells. Angew Chem Int Ed Engl. 2012; 51(17): 4166-70.

PubMed Abstract | Publisher Full Text

85. Seitchik JL, Peeler JC, Taylor MT, et al:: Genetically encoded tetrazine amino acid directs rapid site-specific in vivo bioorthogonal ligation with transcyclooctenes. J Am Chem Soc. 2012; 134(6): 2898-901. PubMed Abstract | Publisher Full Text | Free Full Text

86. Rahim MK, Kota R, Haun JB: Enhancing reactivity for bioorthogonal pretargeting by unmasking antibody-conjugated trans-cyclooctenes. Bioconjug Chem. 2015; 26(2): 352-60.

PubMed Abstract | Publisher Full Text

87. Schmied WH, Elsässer SJ, Uttamapinant C et al: Efficient multisite unnatural amino acid incorporation in mammalian cells via optimized pyrrolysyl tRNA synthetase/tRNA expression and engineered eRF1. J Am Chem Soc. 2014 136(44): 15577-83.

PubMed Abstract | Publisher Full Text | Free Full Text 


\section{Open Peer Review}

\section{Current Peer Review Status:}

\section{Editorial Note on the Review Process}

Faculty Reviews are review articles written by the prestigious Members of Faculty Opinions. The articles are commissioned and peer reviewed before publication to ensure that the final, published version is comprehensive and accessible. The reviewers who approved the final version are listed with their names and affiliations.

\section{The reviewers who approved this article are:}

\section{Version 1}

\section{Christof Niemeyer}

Karlsruhe Institute of Technologie, Karlsruhe, Germany

Competing Interests: No competing interests were disclosed.

\section{Hidde Ploegh}

Massachusetts Institute of Technology, Cambridge, MA, 02139, USA

Competing Interests: No competing interests were disclosed.

\section{Andrew Tsourkas}

University of Pennsylvania, Philadelphia, PA, 19104, USA

Competing Interests: No competing interests were disclosed.

The benefits of publishing with F1000Research:

- Your article is published within days, with no editorial bias

- You can publish traditional articles, null/negative results, case reports, data notes and more

- The peer review process is transparent and collaborative

- Your article is indexed in PubMed after passing peer review

- Dedicated customer support at every stage

For pre-submission enquiries, contact research@f1000.com 